\title{
1. WZROST PKB, RODZINA, JAKOŚĆ ŻYCIA
}

Najistotniejszym elementem $w$ dobrym matżeństwie nie jest szczęście, ale trwałość.

Gabriel García Márquez

\subsection{WPROWADZENIE}

Rodzina i praca są dla większości ludzi dorosłych głównymi środowiskami aktywności i zaangażowania. W literaturze socjologicznej i psychologicznej końca XX w. (np. Cutrona, Eckenrode i Gore oraz Gutek i in.) obecna jest idea przenoszenia zarówno doświadczanych obciążeń emocjonalnych, jak i posiadanych zasobów psychicznych z jednego środowiska do drugiego, co może powodować zarówno pozytywne, jak i negatywne konsekwencje. W teorii występują dwie przeciwstawne koncepcje:

- konflikt między pracą a rodziną (WFC - Work Family Conflict) oraz

- koncepcja wpływów pozytywnych, wzmacniania pełnionych ról: positive spillover (Kirchmeyer 1992), enrichment (Rothbard 2001; Greenhaus, Powell 2006, za: Lachowska 2010).

Jeśli słuszne jest twierdzenie Freuda, że: „warunkiem zdrowia jest zdolność do miłości i do pracy", to wszelkie działania służące lepszemu godzeniu pracy i rodziny wydają się ważne i potrzebne (Witkowska 2002; Lachowska 2010).

Do początków rewolucji przemysłowej w połowie XVIII w. dom rodzinny był najczęściej miejscem pracy. Czyniło to oczywistymi pozytywne związki aktywności rodzinnej i zawodowej. Praca na rzecz domu była zwykle bliska lub tożsama z pracą zawodową. Jak twierdzą historycy w okresie rewolucji przemysłowej nastąpiło nasilone wyprowadzenie pracy zawodowej $\mathrm{z}$ gospodarstwa domowego. Praca zawodowa przynosiła wynagrodzenie finansowe, w odróżnieniu od pracy na rzecz domu. Wzmacniało to postrzeganie relacji między pracą a rodziną jako relacji konfliktowej. Prowadziło to niektórych do wątpliwych 
wniosków o większym znaczeniu pracy zawodowej niż nieopłacanej finansowo pracy na rzecz rodziny.

Życie dla samego siebie jedni są skłonni kojarzyć z nowoczesnością, dążeniem do wolności i atrakcyjnej samorealizacji. Inni oceniają to zjawisko negatywnie, jako sprzeczne ze społeczną i rodzinną naturą człowieka, prowadzące do samotności.

„(...) człowiek jako osoba jest nie tylko członkiem jakiejś społeczności, ale $\mathrm{i}$ istotą społeczną, to znaczy z natury swojej relacyjną. Człowiek staje się osobą w całej pełni, kiedy uczestniczy w życiu innych osób, angażuje się dla innych (dla kogoś), obdarza sobą innych, jest kimś dla drugich”. Człowiek staje się osobą w otoczeniu rodzinnym i w społeczności pracowniczej.

Działanie nakierowane na siebie - samorealizacja - jest pokrewne postawie hedonistycznej. Można postawić pytanie, czy samorealizacja zamiast zaangażowania dla innych nie jest istotną przyczyną relatywnie niskiej jakości życia hedonistów w porównaniu ze zwolennikami eudajmonizmu, dla których najważniejsze jest dążenie do sensu życia, do życia zgodnego $\mathrm{z}$ wyznawanym systemem wartości (Czapiński, Panek 2009).

Każdy ma prawo do kierowania swoim życiem i dokonania indywidualnego wyboru. Choć w niniejszym artykule patrzymy na kapitał społeczny przez pryzmat rodziny, to trzeba przyznać, że niejednokrotnie $\mathrm{w}$ tworzeniu tego kapitału mogą brać udział również osoby żyjące samotnie poprzez poświęcenie swojego czasu (niekiedy i bogactwa) na wsparcie organizacji społecznych i charytatywnych. Alternatywą w przypadku takich osób, negatywną z punktu widzenia korzyści dla społeczeństwa, jest życie dla siebie samego.

W artykule ${ }^{2}$ stawiamy hipotezę, że osłabienie więzi, komunikacji i współpracy rodzinnej, życie dla siebie samego, mierzone ograniczeniem zawieranych małżeństw i nasileniem zjawiska rozwodów ${ }^{3}$, powoduje spowolnienie wzrostu gospodarczego w Polsce.

Przypuszczamy również, że występuje wpływ odwrotny (hipoteza druga): wzrost poziomu gospodarczego i dobrobytu uniezależnia jednostki od siebie,

${ }^{1}$ B. Śliwerski (2011), podobnie W. Irek (2005) pisze, że: „człowiek potrzebuje wielu grup społecznych i kręgów socjalizacyjnych, aby móc w pełni, w sposób komplementarny zrealizować samego siebie".

${ }^{2}$ Punkt 1.2 artykułu został oparty na pierwszej części artykułu J.J. Sztaudyngera (2009), do której wprowadzono drobne zmiany redakcyjne. Punkt 1.4 został zaczerpnięty z artykułu P. Baranowskiego i J.J. Sztaudyngera (2010). Dziękujemy dr E. Lewandowskiemu za kilka uwag wniesionych do naszego tekstu.

${ }^{3} \mathrm{~W}$ uwagach końcowych piszemy o innych miernikach rodzinnego kapitału społecznego, jakie zamierzamy zastosować w dalszych badaniach. 
ułatwia życie w pojedynkę lub dla siebie samego ${ }^{4}$, co ogranicza liczbę zawieranych małżeństw, a także powoduje narastanie zjawiska rozwodów ${ }^{5}$.

W artykule badamy zatem wzajemne oddziaływania dezintegracji rodziny oraz poziomu i wzrostu gospodarczego. Weryfikujemy powyższe hipotezy za pomocą ekonometrycznego modelu wzrostu z rodzinnym kapitałem społecznym.

W punkcie 1.4 próbujemy opisać ożywioną dyskusję o związkach rodzinnego kapitału społecznego ze wzrostem gospodarczym, jaka miała miejsce na kilku konferencjach w latach 2009 i 2010.

\subsection{ZNACZENIE RODZINY - RODZINNEGO KAPITAŁU SPOŁECZNEGO}

Od połowy lat 90. XX wieku w ekonometrycznych badaniach wzrostu gospodarczego coraz większe znaczenie jest przypisywane kapitałowi społecznemu6 ${ }^{6}$. Ważnym składnikiem tego kapitału jest rodzinny kapitał społeczny, kapitał więzi rodzinnych, którego jak dotąd nie próbowano wprowadzić do ekonometrycznych modeli wzrostu. Poniżej podejmujemy taką próbę.

A. Smith nawiązując do stoickiej idei właściwego postępowania i koncepcji Arystotelesa, pisze: „wśród podstawowych celów, do których dążymy z natury, jest pomyślność naszej rodziny, naszych krewnych, przyjaciół, ojczyzny..." (Smith 2006, s. 250).

Najtrwalszymi związkami, jakie łączą ludzi, są więzi rodzinne, tzn. więzi między: małżonkami, rodzicami a dziećmi, dziadkami a wnukami, rodzeństwem. Trwałość i znaczenie związków rodzinnych ma swoje źródła w tradycji, kulturze, religii oraz w samej instytucji małżeństwa ${ }^{7}$. Trwałość i siła związków rodziców z dziećmi jest dodatkowo zależna od naturalnych i instynktownych

\footnotetext{
${ }^{4}$ Przypuszczamy, że życie dla samego siebie, samorealizacja, zwłaszcza z dużą domieszką indywidualizmu, może być swoistym „samogwaltem” albo samoograniczaniem społecznej i rodzinnej natury człowieka. Akceptacja albo odrzucenie wzorca życia dla siebie samego nie są łatwe ani proste m.in. ze względu na to, że samorealizacja wydaje się mieć charakter bardziej krótkookresowy, podczas gdy wzorzec rodzinny często wybiega daleko w przyszłość, dotyczy następnych pokoleń.

${ }^{5}$ Divorce and Economic Growth... (2008).

${ }^{6}$ Punkt 1.2 zbliżony do pierwszej części artykułu J.J. Sztaudyngera (2009, S. 189-210).

${ }^{7}$ L. Kocik (2006, s. 60) zwraca uwagę, że ,instytucja małżeństwa i rodziny była często ważniejsza od wyznania, przynależności etnicznej, obywatelskiej czy narodowej, bowiem je właśnie przecież zmieniano dla usankcjonowania związku małżeńskiego i rodziny”.
} 
więzi macierzyńskich i ojcowskich ${ }^{8}$. Dzieci kierują uczucia nawet do tych rodziców, których nie miały okazji poznać, jak również do tych, którzy w „obiektywnej” ocenie społecznej źle wypełniają zadania rodzicielskie.

W rodzinie najczęściej i najtrwalej kochamy i jesteśmy kochani, od więzi rodzinnych zależy jakość naszego życia, poczucie szczęścia i poczucie bezpieczeństwa $^{9}$. Jak się wydaje, związki z ludźmi spoza kręgu rodzinnego są słabsze i nie są w stanie zastąpić więzi rodzinnych m.in. ze względu na brak ,nieodwoływalnego" pokrewieństwa, brak charakteru instytucjonalnego oraz słabsze kulturowe i religijne podtrzymywanie ich trwałości.

Podstawą rodziny jest małżeństwo ${ }^{10}$. Źródła trwałości rodziny to głównie nierozerwalność związków krwi oraz prawna instytucjonalizacja małżeństwa. Trwałość małżeństwa jest silnie wspierana przez tradycję, kulturę i, zwłaszcza w Polsce, przez religię ${ }^{11}$. Religia katolicka nadaje małżeństwu rangę nierozerwalnego sakramentu. Jan Paweł II w Liście do rodzin podkreśla, że człowiek „nie może odnaleźć się w pełni inaczej, jak tylko poprzez bezinteresowny dar z siebie samego. (...) Dar osoby z istoty swojej jest trwały i nieodwołalny"12.

${ }^{8}$ Podobnie można zauważyć rolę takich więzi w relacjach między wnukami a dziadkami.

${ }^{9}$ Tak pisze o tym A. Smith (1989, s. 325): „Po nim samym (każdym człowieku J.J.S.), członkowie jego rodziny, ci, którzy zazwyczaj mieszkają w jego domu, jego rodzice, dzieci i siostry są naturalnymi obiektami (objects) jego najgorętszych uczuć”.

E. Zubrzycka (1993, s. 95) uzasadnia znaczenie miłości w rodzinie tym, że miłość rodzi wolę wzajemnego zrozumienia, poszanowania, pozwala dać i uzyskać poczucie bezpieczeństwa, rodzi lojalność w dzieleniu pracy i odpowiedzialności.

F. Adamski (2002, s. 41-42) twierdzi, że przede wszystkim w rodzinie człowiek może zaspokajać potrzebę uczuć i ma to ogromny wpływ na jego postawę i aktywność życiową.

${ }^{10}$ Rodziną w ujęciu tradycyjnym nazywamy małżonków i ich dzieci (również adoptowane), a także osoby związane pokrewieństwem lub powinowactwem (Stownik języka polskiego, 1999, s. 64). Podejmowane są próby poszerzenia zakresu pojęcia rodziny o związki kohabitacyjne. W języku angielskim pojęcie rodziny jest bardziej, niż w języku polskim, zbliżone do pojęcia gospodarstwa domowego.

${ }^{11}$ Rolę religii podkreślał już A. Smith (1989, s. 353): „Zarządzanie wielkim organizmem wszechświata, troska o powszechne szczęście wszystkich racjonalnych i rozumnych istot jest jednakże sprawą Boga, a nie człowieka. Człowiekowi powierzono znacznie skromniejszy dział ... troskę o własne szczęście, o szczęście jego rodziny, o szczęście jego kraju...”.

12 Jan Paweł II (1994). List do rodzin nie ma charakteru naukowego, przytaczamy go jako ilustrację stanowiska Kościoła, które wpływa istotnie na postawy ludzi. Znaczenie rodziny jest bowiem mniejsze dla osób, które deklarują mały udział w praktykach religijnych, por. Nie ma jak rodzina (2008, s. 5). Badanie zrealizowano na reprezentatywnej, losowej próbie 1137 dorosłych mieszkańców Polski, w dniach 1-4 lutego 2008. 
Mimo tak jednoznacznej deklaracji trwałości i nieodwoływalności małżeństwa, prawo kanoniczne Kościoła Katolickiego przewiduje w pewnych szczególnych okolicznościach unieważnienie małżeństwa. Następuje to m.in. w sytuacjach, kiedy już w momencie zawierania małżeństwa zachodziły okoliczności na tyle istotne $\mathrm{z}$ punktu widzenia możliwości jego funkcjonowania, które nie pozwalały uznać je za ważne ${ }^{13}$.

W kontekście szerszym niż rodzinny, Z. Bauman (2007, s. 357-358) przypomina pytanie Jana Pawła II: „Czy osoba może się w pełni realizować, nie uwzględniając swej natury społecznej bycia »z« innymi i »dla« innych?"14. I odpowiada: „Bycie »z« czyni odpowiedzialność za innych losem nieodwracalnym człowieka, gdy bycie »dla«, uznanie i przyjęcie tej odpowiedzialności za zasadę życia, wynosi owo zrządzenie losu do rangi powołania. (...) Być osobą to tyle, ile zdać sobie sprawę z odpowiedzialności za innych, zgodzić się na tę odpowiedzialność i uznać, że choć wszyscy jesteśmy sobie nawzajem winni odpowiedzialność, to ja i tylko ja odpowiadam za wywiązanie się ze swojej"15. Dezintegracja rodziny, a w krańcowych przypadkach rozwód jest kryzysem odpowiedzialności każdego z małżonków ${ }^{16}$.

L. Kocik twierdzi, że rodzina „(...) wiąże osobę ludzką we wszystkich fazach jej życia ze społeczeństwem, kulturą, narodem, klasą społeczną. Motywuje jej aktywność ekonomiczną, społeczną i kulturalną, kształtuje cechy osobowości człowieka" (Kocik 2006, s. 58). Podobnie Z. Tyszka pisze, że mikroświat rodziny jest wkomponowany w system ogólnospołecznych, ekonomicznych i kulturalnych procesów danego kraju ${ }^{17}$.

„(...) ludzie w stanie małżeńskim są szczęśliwsi niż w stanie wolnym (Czapiński, Panek 2009, s. 171-173), mają wyższe dochody, doświadczają ciepła i emocjonalnego wsparcia, (...) żyją dłużej niż osoby wolnego stanu cywilnego" (Slany 2003, s. 41-42).

Na przełomie XX i XXI w. silne ataki na instytucję rodziny prowadzono na forum ONZ. W dokumentach sesji nadzwyczajnych ONZ próbowano m.in. zastąpić słowo family słowem partnership. Istotną rolę $\mathrm{w}$ zablokowaniu tych prób odegrali przedstawiciele Polski, por. J. Kropiwnicki (2008, s. 183-189).

${ }^{13}$ Według zasad kodeksu cywilnego w podobnych sytuacjach orzekany jest rozwód. Można więc stwierdzić, że nawet w rygorystycznych zasadach Kościoła Katolickiego dopuszcza się możliwość i celowość rozejścia się kobiety i mężczyzny.

${ }^{14}$ Pytanie to Jan Paweł II zadał w orędziu na Światowy Dzień Pokoju w 2005 r.

15 Z. Bauman (2007, s. 358). Por. E. Podrez (2008, s. 57).

${ }^{16}$ Kryzys odpowiedzialności Z. Bauman nazywa kryzysem człowieczeństwa.

${ }^{17}$ Z. Tyszka (1980), cyt. za L. Kocikiem (2006., s. 59), który dodaje, że ,analiza życia rodzinnego nie może ograniczać się wyłacznie do spraw wewnątrzrodzinnych, lecz musi również dotyczyć zewnętrznych relacji rodziny - jej osadzenia w społeczeństwie, jego strukturach, procesach i kulturze”. 
„(...) Dobra rodzina tworzy najlepsze środowisko dla pierwotnej, najgłębszej socjalizacji, stanowiąc niezastąpione dla jednostki źródło poczucia bezpieczeństwa i stabilności, ale też inspiracji do rozwoju i samorealizacji” (Kocik 2006, s. 314).

W powyższych wypowiedziach pojawia się motyw związków rodziny z systemem ekonomicznym i rozwojem jednostki - rozwojem kapitału ludzkiego.

Można podać szereg przykładów, kiedy osoby $\mathrm{z}$ harmonijnym życiem rodzinnym, żyjące $\mathrm{w}$ związku małżeńskim, są wyżej oceniane niż osoby stanu wolnego. Przy naborze menedżerów na najbardziej odpowiedzialne stanowiska biznesowe ich życie rodzinne jest brane pod uwagę, jako ważne kryterium i prognostyk walorów ich przyszłej pracy. Podobnie, przy ubieganiu się o kredyt bankowy, pozostawanie w związku małżeńskim zdecydowanie podnosi zdolność kredytową i prawdopodobieństwo uzyskania kredytu ${ }^{18}$.

Już ponad 200 lat temu A. Smith twierdził, że trwałość i znaczenie rodziny maleje na skutek rozwoju cywilizacji związanego z rosnącą prawną ochroną nawet „,najskromniejszego człowieka” (Smith 1989, s. 331-332).

Współczesną próbą opisania spadku znaczenia rodziny jest teoria drugiego przejścia demograficznego (od ok. 1960 r.). Przejście to polega na dążeniu jednostki do samorealizacji i autonomii, odrzucaniu wartości tradycyjnych na rzecz liberalnych, poprawie warunków życia ludności w wyniku rozwoju usług i postępu technicznego. Ta poprawa warunków życia m.in. ułatwia życie w pojedynkę i redukuje stopień wzajemnej zależności członków rodziny. Na skutek drugiego przejścia demograficznego „(...) rodzina i dziecko mają mniejsze znaczenie, niż para czy jednostka”. Uwidacznia się wzrost znaczenia związków alternatywnych względem rodziny (Slany 2003, s. 31).

Przez rodzinny kapitał spoleczny (kapital rodzinny) rozumiemy więzi między członkami rodziny, które im służą i równocześnie nie są w sprzeczności $\mathrm{z}$ interesem społecznym. Więzi te wyrażają się w postawach szacunku, zaufania, miłości, zainteresowania, opieki, pomocy i troski o członków rodziny.

Kapitał rodzinny będziemy mierzyć relacją małżeństw do liczby ludności (pozytywny kapitał rodzinny) oraz relacją rozwodów do liczby ludności (negatywny kapitał rodzinny) ${ }^{19}$. Relacje te traktujemy jako wskaźniki:

${ }^{18}$ Ważnym przykładem wspierania rodzin w tej dziedzinie jest, cieszący się bardzo dużą popularnością, program „Rodzina Na Swoim” oferujący preferencyjne kredyty z dopłatą Skarbu Państwa na zakup mieszkania lub domu.

${ }^{19}$ Ponieważ rośnie liczba par, które żyją razem bez formalnego powiązania (kohabitują), pojawia się wątpliwość co do adekwatności współczynnika - relacji rozwodów do małżeństw. Związki kohabitacyjne, które nie kończą się małżeństwem, nie kończą się również rozwodem. A zatem w proponowanym współczynniku zmniejsza się równocześnie licznik i mianownik, co w niewielkim stopniu łagodzi problem. 
1. Trwałości (nietrwałości) rodziny,

2. Wzmocnienia (osłabienia) więzi rodzinnych (kapitału rodzinnego),

3. Wzmocnienia (osłabienia) umiejętności komunikacji i współpracy rodzinnej oraz społecznej (w tym ekonomicznej i zawodowej) ${ }^{20}$,

4. Malejącej (rosnącej) niepewności i ryzyka w życiu ludzi ${ }^{21}$, ponieważ nie można w pełni zastąpić więzi rodzinnych więziami z osobami spoza kręgu rodzinnego.

W Polsce na początku lat 60. XX w. liczba zawieranych małżeństw wynosiła ok. 230 tys. W roku 2011 spadła do 207 tys. Natomiast liczba rozwodów wzrosła ponad czterokrotnie z ok. 18 do 75 tys. w 2011 r.

Nie każdy rozwód zmniejsza rodzinny kapitał społeczny. Przy długotrwałym konflikcie małżonków, kiedy małżeństwo nie realizuje dostatecznie wielu ważnych funkcji, nie zapewnia opieki, bezpieczeństwa, troski, nie zaspokaja potrzeb uczuciowych i emocjonalnych, rozwód jest mniejszym złem, niż trwanie w małżeństwie za wszelką cenę.

W praktyce poprowadzenie granicy, poza którą małżonkowie powinni się rozwieść jest nieskończenie trudne. Trudność ta wynika z konieczności uwzględnienia interesu wszystkich jej członków, również dzieci ${ }^{22}$, nie tylko w okresie rozwodu, ale również później - do końca ich życia, a nawet życia następnych pokoleń.

A. Giddens (2006, s. 17) podkreśla, że skutkiem rozwodów jest utrata ,zaufania do własnych sądów i możliwości”, a osoby rozwodzące się zniechęcają się

Można również argumentować, że 40\% takich par przekształca się w małżeństwo (w USA, według Castellsa), a wtedy są już uwzględniane w naszym wskaźniku. Spośród tych małżeństw aż 50\% kończy się rozwodem (Slany 2003, s. 43-44). A więc można uznać, że jedną z przyczyn narastania zjawiska rozwodów jest rosnąca popularność kohabitacji, z których powstają mniej trwałe małżeństwa. K. Slany zauważa, że w związki kohabitacyjne nie inwestuje się (emocjonalnie i materialnie, w tym w dzieci). Natomiast „(...) w przypadku małżeństwa istnieje pewność, że inwestycja jest prawnie i społecznie chroniona” (Slany 2003, s. 44, 49).

${ }^{20} \mathrm{Na}$ ten aspekt rozwodów zwrócił uwagę P. Starosta (19.11.2008, rozmowa bezpośrednia).

21 „Rodzina posiada ogromną wartość społeczną (...) jako czynnik stabilizujący jednostkowe i społeczne życie” (Kocik 2006, s. 63). Do zadań rodziny należy m.in. ,(...) zapewnienie wszystkim jej członkom poczucia bezpieczeństwa i szacunku" oraz odpowiednich warunków materialnych (Zubrzycka 1993, s. 97). Oba wymienione zadania mają bardzo ważne znaczenie dla efektywnego uczestniczenia ludzi w tworzeniu produktu krajowego.

${ }^{22}$ Interes dzieci jest szczególnie trudny do określenia, zwłaszcza gdy dzieci nie są dorosłe. Wtedy interes dzieci próbują wyrażać dorośli. Powoduje to, że interes dzieci nie jest najczęściej wystarczająco reprezentowany - por. J.S. Wallerstein i S. Blakeslee (2006). 
(...) do stawiania sobie nie tylko dalekosiężnych celów, a nawet doraźnych celów, a tym bardziej nie działają w kierunku realizacji zamierzeń".

Dlatego też stawiamy hipotezę, iż dezintegracja rodzin - wzrost rozwodów do relacji liczby ludności oraz spadek małżeństw w relacji do liczby ludności powoduje spowolnienie wzrostu gospodarczego ${ }^{23}$. A zatem rozwody są korelowane ze spowolnieniem gospodarki nie jako przyczyna, ale jako reprezentant rzeczywistej przyczyny, jaką jest dezintegracja rodzin.

W tradycji większości społeczeństw małżeństwo jest najbardziej publiczną i najbardziej uroczyście zawieraną umową o współdziałaniu. Wagę tej umowie nadaje również to, że jest zawierana na czas nieograniczony (zazwyczaj: ,aż do śmierci"). Umowa ta ma m.in. rangę państwową, jest rejestrowana przez odpowiednie instytucje, a jej rozwiązanie wymaga najczęściej rozstrzygnięcia sądowego. Rozwód, czyli niedotrzymanie tej szczególnej umowy jaką jest małżeństwo, ogranicza zaufanie co do dotrzymywania innych umów. W szczególności sądzimy, że może to podważać zaufanie do wypełniania różnorodnych zobowiązań związanych z pracą zawodową ${ }^{24}$.

\subsection{MODEL WZROSTU GOSPODARCZEGO Z RODZINNYM KAPITALEM SPOŁECZNYM ${ }^{25}$}

Ekonometryczny model wzrostu zawiera sześć równań stochastycznych oszacowanych zwykłą metodą najmniejszych kwadratów. Schemat tego modelu przedstawia rys. 1 .

W najbardziej istotnym, ze względu na cel badania, równaniu 1 wzrost PKB zależy parabolicznie od rozwodów. $Z$ równania paraboli wynika, że najszybszy wzrost PKB byłby osiągany dla współczynnika 0,62 rozwodów na 1000 osób. $\mathrm{W}$ badanym okresie współczynnik ten przyjmował wartości z przedziału od 0,8 do 1,9 . Wynika stąd, że w całym badanym okresie liczba rozwodów była zbyt duża i spowalniała wzrost gospodarczy. W XXI w., kiedy współczynnik ten przyjmował największe wartości 2 rozwody na 3 spowalniały wzrost gospodarczy. W tych szacunkach uwzględniany jest wyłącznie wpływ, tak aproksymowanej dezintegracji rodziny, na dorosłych pracujących członków

${ }^{23} \mathrm{~W}$ dalszych badaniach będziemy stosować wskaźnik liczby rozwodów do ogólnej liczby istniejących małżeństw.

${ }^{24} \mathrm{~W}$ porozumiewaniu się pracodawców z pracownikami za najważniejsze uznano dotrzymywanie umów (ok. 75\%). Było ono ważniejsze m.in. od zaufania, rzetelnej informacji i przygotowania merytorycznego (na podstawie badania ankietowego ponad 1200 osób) (Fedorczuk, Kliszko, Męcina 2009, s. 70-72).

${ }^{25}$ Pierwowzorem modelu prezentowanego w tym punkcie są fragmenty artykułu J.J. Sztaudyngera i W. Zatonia (2010, s. 109-128). Nowe są równania małżeństw i rozwodów, jak również funkcja wzrostu gospodarczego zawierająca te zmienne. 
rodziny. Natomiast nie jest niestety uwzględniany wpływ międzypokoleniowy na dzieci $\mathrm{z}$ nietrwałych rodzin, który będzie miał miejsce $\mathrm{w}$ przyszłości, w okresie ich pracy zawodowej.

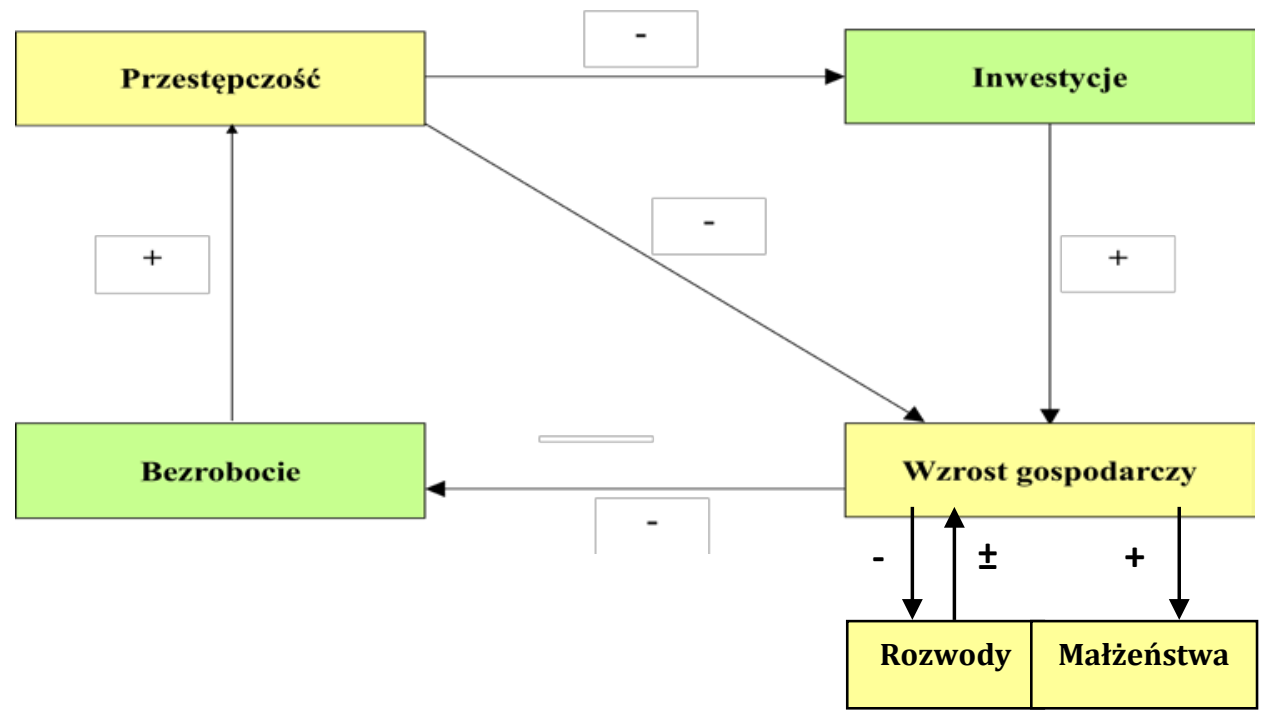

Rys. 1. Schemat modelu wzrostu gospodarczego

(równania modelu zostały przedstawione w załączniku)

Źródło: oprac. własne

\subsection{ARGUMENTY OPONENTÓW I NASZE ODPOWIEDZI}

Do hipotezy o wpływie liczby małżeństw i rozwodów na wzrost gospodarczy zgłaszano szereg zastrzeżeń.

1. „Związek między małżeństwami, rozwodami a wzrostem gospodarczym ma charakter symptomatyczny - jest pozorny, a nie przyczynowo-skutkowy”. Uważamy, że rozstrzygnięcie tego sporu może nastąpić wyłącznie w drodze dyskusji poprzedzającej oszacowanie modelu. Istotne oszacowania parametrów przy współczynnikach małżeństw rozwodów w pewnym stopniu uprawdopodabniają badaną hipotezę. Nie mogą natomiast zniwelować podejrzenia o to, że związek ten jest pozorny. W artykule wcześniejszym ${ }^{26}$, jak i niniejszym zasadniczy tok argumentacji był następujący:

- życie rodzinne jest bardzo ważne dla większości ludzi;

${ }^{26}$ J.J. Sztaudynger (2009). 
- małżeństwo jest szczególnie trwałą (w świadomości wielu osób nierozerwalną) umową o współpracy, a rozwód nadzwyczajnym niedotrzymaniem tej umowy, dla wielu członków rodziny ma wymiar katastrofy życiowej; jak twierdzą J.S. Wallerstein i B. Blakeslee (2006), czas nie łagodzi w pełni skutków tego wydarzenia;

- duża liczba decyzji małżeńskich oraz mała liczba decyzji rozwodowych świadczy o dużej, społecznej skłonności do nawiązywania współpracy nie tylko w rodzinach, ale również w miejscach pracy; świadczy o dużej skłonności do kooperacji (P. Starosta);

- skłonność do współpracy (podobnie jak zaufanie do innych ludzi) dynamizuje wzrost gospodarczy.

2. „Wpływ relacji małżeństw i rozwodów na wzrost gospodarczy ma charakter pozorny". Można stosować testy przyczynowości, aczkolwiek możliwość rozstrzygnięcia tej wątpliwości jest ograniczona. Ponieważ zdarzenie poprzedzające może być przyczyną i nie może być skutkiem zdarzenia następującego, rezultaty nasze mogą wskazywać, iż dezintegracja rodziny reprezentowana przez rozwody może być przyczyną wzrostu spowolnienia gospodarczego. Test przyczynowości Grangera pozwala $\mathrm{z}$ wysokim prawdopodobieństwem $(0,98)$ stwierdzić, że dezintegracja rodziny (reprezentowana przez współczynnik rozwodów) jest przyczyną kształtowania się wzrostu gospodarczego (w Polsce $)^{27}$.

3. „Jak już pisaliśmy, ponieważ w przedstawionych modelach współczynniki rozwodów i małżeństw są opóźnione, można wykluczyć, że prezentowane modele wyrażają związek przeciwny do związku w nim występującego (takie niebezpieczeństwo mogłoby występować, gdyby w modelu nie było opóźnienia). Natomiast możliwość korelacji pozornej w dalszym ciągu występuje.

4. „Współczesne przedsiębiorstwa opierają swój rozwój na całkowitej dyspozycyjności, czyli m.in. na tym, że młodzi pracownicy praktycznie nie mogą zakładać rodzin, mieć dzieci itd." - M. Czyżewski ${ }^{28}$. To jest argument-hipoteza dotycząca negatywnego wpływu dyspozycyjności pracowniczej (i wzrostu gospodarczego) na liczbę małżeństw ${ }^{29}$. W świetle uzyskanych wyników wpływ wzrostu gospodarczego na małżeństwa jest pozytywny.

${ }^{27}$ Przyczyną w sensie Grangera. Test ten nie wyklucza możliwości występowania korelacji pozornej.

${ }^{28}$ M. Czyżewski nazywa to kapitalizmem antyrodzinnym i odnosi to głównie do okresu po 1989 r. Problem ten będzie badany w równaniu, w którym współczynnik dezintegracji małżeństw będzie uzależniany od wzrostu gospodarczego (rozmowa bezpośrednia, wrzesień 2009).

${ }^{29}$ Współczynnik dezintegracji małżeńskiej będzie wtedy rósł (podobnie jak przy wzroście liczby rozwodów). 
5. Są to argumenty na rzecz hipotezy o konflikcie między pracą a rodziną (work family conflict), którą można nazwać również hipotezą substytucyjności: im lepszy pracownik, tym gorzej wypełnia swoje role rodzinne. My opowiadamy się na rzecz i potwierdzamy hipotezę odwrotną wpływów pozytywnych, wzmacniania ról (równania 1, 5 i 6). Można nazwać to hipotezą komplementarności ${ }^{30}$ : im większy sukces osiagga pracownik w miejscu pracy, tym lepiej wypełnia swoje role rodzinne i odwrotnie. W rzeczywistości sytuacje substytucyjne i komplementarne nakładają się na siebie. Uzyskane wyniki pozwalają przypuszczać, że dominuja sytuacje komplementarnego wspierania rodziny przez dynamiczna gospodarke i odwrotnie.

6. „Zmiany przepisów prawnych regulujących małżeństwa, rozwody i separacje”. Zgoda. Uzyskane rezultaty pozwalają stwierdzić, że zmiany te były na tyle małe, że badanie wpływu współczynnika rozwodów na wzrost jest możliwe. Dodajmy, że zmienna interakcyjna wyrażająca wprowadzenie od 2000 roku separacji okazała się nieistotna.

7. „Po rozwodzie kobiety częściej podejmują pracę i bardziej wydajnie pracują, co się przyczynia do wzrostu PKB”. Jedną z przyczyn jest przymus ekonomiczny lub dążenie do zachowania ,przedrozwodowego" poziomu życia. Obciążenie pracą zawodową i obowiązkami domowymi bywają w takiej sytuacji nadmierne, wyniszczające (Wallerstein, Blakeslee 2006). Można przypuszczać, że w krótkim okresie wystąpi efekt pozytywny dla wzrostu (byłby to efekt substytucyjny), natomiast w okresie długim skutki będą prawdopodobnie negatywne (efekt komplementarny).

Efekt pozytywny jest w tym przypadku pewną iluzją statystyczną. Na przykład: kobieta przed rozwodem nie pracowała zawodowo, zajmowała się dzieckiem w wieku przedszkolnym. Po rozwodzie kobieta podejmuje pracę zawodową (wzrost PKB), a dziecko posyła do przedszkola (również wzrost PKB). Jeśli dziecko miało lepszą opiekę w domu niż w przedszkolu, ten drugi wzrost PKB jest iluzją statystyczną, ponieważ statystyka nie wlicza pracy w gospodarstwie domowym do PKB. Natomiast jeśli prace domowe zostają przekazane instytucjom usługowym, wtedy są zaliczane do PKB.

8. „Po rozwodzie potrzebne jest dodatkowe mieszkanie dla jednego z byłych współmałżonków, czasami również drugi samochód. Rośnie zatem popyt, zwłaszcza w dobra trwałego użytkowania”. Zgoda, ale jest to możliwe tylko przy wzroście sumarycznych dochodów byłych współmałżonków.

Warto nadmienić, że dla Polski stwierdzono dodatni wpływ współczynnika rozwodów na inwestycje, co, za ich pośrednictwem, przyspiesza wzrost gospodarczy. Równocześnie bezpośredni negatywny wpływ współczynnika rozwodów

\footnotetext{
${ }^{30}$ M. Czyżewski używa tu określenia kapitalizm prorodzinny.
} 
na wzrost jest dziesięć razy większy, a zatem wpływ sumaryczny jest negatywny (Sztaudynger 2009, s. 202).

9. Wiele podanych argumentów odnosi się do rozwodzących się małżonków i skutków bezpośrednio ich dotyczących. Wydaje się, że bardziej znaczące są efekty pośrednie, przez które rozumiemy wzrost poczucia niepewności małżeńskiej i rodzinnej u osób, które mają styczność z rozwodzącym się małżeństwem. Wzrost niepewności, obawa o trwałość własnego małżeństwa, lęk podjęcia decyzji o małżeństwie wpływają negatywnie na integrację wszystkich rodzin, powodują spadek jakości życia. To z kolei obniża wydajność pracy i spowalnia wzrost gospodarczy.

10. Ponieważ relacja współpracy jest relacją zwrotną, wyżej wymienione, niekorzystne zjawiska wpływają pośrednio na całe zespoły pracownicze, w których pracują albo którymi kierują osoby z rodzin dotkniętych rozwodem.

11. Duża liczba rozwodów charakteryzuje nietrwałość i pogorszenie relacji międzyludzkich we wszystkich rodzinach, a nie tylko tych, które zostały bezpośrednio dotknięte rozwodem (tak jak wysoka śmiertelność świadczy o złym stanie zdrowotności całego społeczeństwa). Przypuszczamy, że wielość rozwodów w relacji do liczby małżeństw jest symptomem pogarszających się relacji międzyludzkich we wszystkich rodzinach i miejscach pracy.

12. J. Growiec (mail 05.07.2009) zwraca uwagę, że rodzinny kapitał społeczny mierzy się w socjologii częstotliwością kontaktów z rodziną, lecz nie uwzględnia współmałżonka. Tak określony kapitał rodzinny zalicza się do kapitału separującego (bonding), który ma spowalniać wzrost gospodarczy (Putnam 1995; Sabatini 2006, Beugelsdijk, Smulders 2009; Growiec, Growiec 2010).

My natomiast proponujemy mierzenie trwałości i jakości relacji rodzinnych za pomocą częstotliwości zawierania małżeństw i częstotliwości rozwodów. Małżeństwo jest początkiem nowej, tradycyjnie pojmowanej rodziny. Rozwód nie stanowi, co prawda, końca rodziny, ale jest przejawem jej bardzo poważnego kryzysu. Dlatego proponujemy, aby był to jeden $\mathrm{z}$ mierników rodzinnego kapitału społecznego. Przypuszczamy, że przyrost rodzinnego kapitału społecznego, mierzony relacją zawieranych małżeństw do liczby ludności, charakteryzuje gotowość do budowania trwałych więzi i współpracy osób (przyszłych małżonków). Małżonkowie najczęściej nie znają się uprzednio, pochodzą często z odmiennych grup społecznych, narodowych itp. Odwrotnie - rozwód jest rozwiązywaniem więzi i współpracy między osobami potencjalnie najbliższymi (kulturowo, uczuciowo, instytucjonalnie, tradycyjnie, religijnie), jakimi są współmałżonkowie. Przyjęty miernik charakteryzuje zatem pomostowy (bridging) rodzinny kapitał społeczny.

13. Zasadnicza konkluzja naszych rozważań jest następująca: współzależność rodziny i gospodarki powoduje, że wzrost zrównoważony wymaga ochrony 
środowiska rodzinnego. Współpracownicy powinni zatem wspierać się nawzajem w pełnieniu ról rodzinnych. Pracodawcy, dążąc do integracji pracowników, nie powinni tego robić kosztem ich rodzin. Wszystkie te powinności uzasadnimy współzależnością rodziny i gospodarki.

W stosunku do tej konkluzji formułowany jest zarzut, że ma ona charakter ocenny, aksjologiczny i że nie jest sądem naukowym. Proszę jednak zwrócić uwagę, że używamy określenia powinna, w kontekście konsekwencji ekonomicznych dla wzrostu gospodarczego ${ }^{31}$. Jest to oczywiście tylko jeden, spośród wielu, negatywny wymiar wpływu nietrwałej rodziny na życie każdego z nas ${ }^{32}$. Akceptacja proponowanego podejścia i uzyskanych rezultatów dostarcza argumentów na rzecz tradycyjnego modelu rodziny ${ }^{33}$. Jak twierdzi J. Dzionek-Kozłowska (2006, s. 76) „(...) niemożliwe jest formułowanie niezależnych i oderwanych od wartości zaleceń odnośnie problemów bieżących ${ }^{34 » ” . ~ J . ~ G o d-~}$ łów-Legiędź (mail do autora 12.07.2010) dodaje: „(...) rozwój ekonomiczny ma głębokie uwarunkowania w sferze systemów wartości, a współcześnie zachodzą takie zmiany, które podważają fundamenty tego rozwoju. Kryzys finansowy to wyraźnie pokazuje. Podstawową kwestią wydaje się być szeroko rozumiane poczucie odpowiedzialności jednostki i pojmowanie ludzkiej wolności”.

Według reguły Poppera teorie są naukowe wtedy, gdy można je sfalsyfikować i nigdy poza tym, co w ostatecznej instancji oznacza wypowiedzieć prognozę, że to a to nastąpi, albo nie nastąpi. Na takie prognozy najczęściej nie

${ }^{31}$ Zostało to zweryfikowane ekonometrycznie. Model może być użyty do prognoz. Argumenty te mają znaczenie tylko dla czytelników, którzy uznają badane związki za przyczynowo-skutkowe, a nie pozorne.

${ }^{32} \mathrm{~W}$ podobnym kierunku zmierzają zalecenia socjolog K. Slany (2003, s. 49-50), która pisze, że: „Małżeństwu i rodzinie należy przywrócić wartość. Odbudowa winna być prowadzona przez same rodziny, kościół, grupy sąsiedzkie, środki masowego przekazu, nie zaś przez subsydia państwowe, programy rządowe (...). Należy ją wspierać i podkreślać jej uniwersalne wartości. Jest przecież podstawą naszego trwania, podstawą naszej moralności i podstawą społecznej organizacji. Rodzina jest najpotężniejszym kapitałem społecznym; jej formowanie jest i winno być najważniejszym typem inwestowania w społeczny kapitał”.

${ }^{33}$ Gdybyśmy uzasadniali tezę, że należy dbać o trwanie, trwałość przyrody i środowiska naturalnego, bo służy to zrównoważonemu wzrostowi i jakości życia, zarzut o nienaukowych kontekstach światopoglądowych nie byłby pewnie formułowany.

${ }^{34}$ Powołuje się ona np. na A. Marshalla, w którego tekstach ,,pojawia się myśl, iż ekonomiści unikają wypowiadania się na temat moralności, ponieważ wraz z uzyskaniem przez ekonomię statusu samodzielnej dyscypliny naukowej po prostu utracili umocowanie do rozstrzygania tego rodzaju kwestii”. Sam Marshall poniósł spektakularną porażkę w uprawianiu ekonomii pozytywnej. W swoich pracach nauczał ludzi, że mają panować nad sobą, wykazywać umiar, dyscyplinę wewnętrzną i kreatywność (Dzionek-Kozłowska 2006, s. 75). 
pozwalają sądy wartościujące (Blaug 1994, s. 699). W naszym jednak przypadku hipoteza, że trwała rodzina przyspiesza wzrost gospodarczy jest weryfikowana w oparciu o model ekonometryczny, z którego prognozy również mogą być weryfikowane.

\subsection{Podsumowanie}

Analizowano wzajemne oddziaływania między dezintegracją rodziny oraz poziomem i wzrostem gospodarczym. Potwierdziliśmy hipotezę, że osłabienie więzi rodzinnych, mierzone nasileniem zjawiska rozwodów powodowało spowolnienie wzrostu gospodarczego w Polsce. Nie potwierdziliśmy drugiej hipotezy, że wzrost poziomu gospodarczego i dobrobytu ogranicza liczbę zawieranych małżeństw. Wzrost poziomu gospodarczego oddziałuje pozytywnie na liczbę zawieranych małżeństw, jeśli w równaniu występuje zróżnicowanie płac $\mathrm{GINI}^{35}$. Natomiast potwierdzono hipotezę o tym, że wzrost poziomu gospodarczego powoduje narastanie zjawiska rozwodów.

Analizę prowadziliśmy przy założeniu, że między rodziną a gospodarką występują zależności przyczynowo-skutkowe, co próbowaliśmy uzasadnić w punkcie 4. Uzyskane wyniki uprawdopodobniają występowanie takich związków, aczkolwiek nie są w stanie zniwelować podejrzeń o korelacje pozorne.

W naszych analizach miernikiem wzrostu gospodarczego jest, często krytykowana, dynamika PKB. My również uważamy ten miernik za zbyt jednostronny i podzielamy postulaty uwzględnienia również takich miar, jak długość życia, zadowolenie z życia, zanieczyszczenie środowiska naturalnego, przestępczość. Alternatywne względem PKB mierniki ciągle są i będą przedmiotem sporów, ponieważ wagi poszczególnych mierników dobrobytu stosowane do budowy miernika syntetycznego są dobierane arbitralnie. Lepszym rozwiązaniem wydaje się podejście zaproponowane w artykule - uzależnienie niedoskonałego miernika, jakim jest PKB, od komponentów dobrobytu. Uważamy, że wzrost gospodarczy może być dynamiczny tylko w warunkach dobrobytu i harmonii. Warunki takie to trwała rodzina (ograniczenie liczby rozwodów o ok. 2/3), optymalne zróżnicowanie dochodów, niska przestępczość.

W większości krajów, w reprezentatywnych badaniach ankietowych, określa się jakość życia. W badaniu pod auspicjami czasopisma "The Economist" analizowano, od czego zależy jakość życia w $111 \mathrm{krajach}^{36}$. Wagę

${ }^{35}$ Jeśli z równania małżeństw usuniemy zmienną GINI, znak oceny parametru przy PKB per capita zmienia się na negatywny.

${ }^{36}$ The Economist Intelligence Unit's quality-of-life index, The World in 2005, www.economist.com/media/pdf/QUALITY_OF_LIFE.pdf, odczyt 10.11.2012. 
poszczególnych determinantów oszacowano za pomocą modelu ekonometrycznego. Potwierdzono, że na jakość życia wpływa PKB per capita (19\%), przeciętne trwanie życia (19\%), częstotliwość rozwodów (11\%) i kilka innych czynników, (suma wag równa jest 100\%, dla roku 2005). Potwierdzono zatem, że bardzo znaczącym wyznacznikiem jakości życia jest materialny poziom życia (PKB per capita), ale równie ważny jest miernik stanu zdrowia, za jaki uważamy przeciętne trwanie życia. Niższą, ale istotną statystycznie, wagę ma częstotliwość rozwodów (11\%). Potwierdza to negatywny wpływ rozwodów na jakość życia.

Zamierzamy powiększyć zbiór mierników rodzinnego kapitału społecznego o dzietność kobiet, relacje związków partnerskich do liczby istniejących małżeństw (oszacowanie na podstawie frakcji urodzeń dzieci pozamałżeńskich) oraz przeciętną liczbę osób w gospodarstwie domowym.

W dalszych badaniach będziemy weryfikować hipotezę o oddziaływaniu nowo zawieranych małżeństw na wzrost gospodarczy za pośrednictwem dzietności. W modelu zostanie uwzględniona struktura demograficzna oraz dodane równanie przeciętnego trwania życia.

ZALĄCZNIK

Równania modelu wzrostu gospodarczego z rodzinnym kapitałem społecznym

1. Równanie wzrostu gospodarczego - wzrostu PKB

$$
\begin{aligned}
& \dot{X}=-4,6+0,32 \Delta I / X-14,7 \dot{C} r_{0-1} \\
& 0,9 \quad 1,4 \quad 8,0 \\
& +28,1(\mathrm{rozw} / \mathrm{lud})_{-5}-17,3(\mathrm{rozw} / \mathrm{lud})_{-5}^{2}-10,3 \text { u } 79 \_81 \\
& 2,5 \quad 3,0 \quad 9,1 \\
& \mathrm{R}^{2}=0,869 \quad \mathrm{DW}=1,65 \quad \mathrm{~S}_{\mathrm{e}}=2,0 \quad \text { okres analizy } 1965-2006
\end{aligned}
$$

\section{Równanie wzrostu zatrudnienia (pracujących)}

$$
\begin{aligned}
& \dot{L}_{t}=0,88+0,155 \dot{X}_{t-1}-0,144(I / X)_{t-1}-0,031 u 99 \_03-0,044 u 90 \_93 \\
& \begin{array}{lllll}
26,1 & 4,8 & 3,0 & 7.2 & 8,1
\end{array} \\
& \mathrm{R}^{2}=0,854 \quad \mathrm{DW}=1,44 \quad \mathrm{~S}_{\mathrm{e}}=0,0089 \quad \text { okres analizy } 1968-2006
\end{aligned}
$$




\section{Równanie poziomu stopy przestępczości}

$$
\begin{aligned}
& \ln c r=-2,32-0,0033\left(X p c / X p c_{-2}-1\right)+0,22 \sum_{i=0}^{3} \ln X p c_{-i}+ \\
& 5,6 \quad 2,8 \quad 10,3 \\
& -0,34\left(\ln S+\ln S_{-1}\right)+0,0091 \sum_{i=0}^{4} \ln B B_{-i}+0,23 u 83 \_87 \\
& 20,8 \quad 19,4 \quad 8,6 \\
& \mathrm{R}^{2}=0.993 \quad \mathrm{~S}_{\mathrm{e}}=0.04 \quad \mathrm{DW}=2,62 \quad \text { okres analizy 1978-2006 }
\end{aligned}
$$

\section{Równanie stopy inwestycji}

$$
\begin{aligned}
& I / X=22.6+3197\left(\dot{X} / L_{0-7}\right)^{3}-5.98 \dot{c r_{-1-5}}+0,0064\left[(\text { rozw } / \text { lud })_{-3}-(\text { rozw } / \text { lud })_{-5}\right]-3,8 U 67 \_71-3,3 U 03 \_06 \\
& \begin{array}{rrrrrr}
67,3 & 3,7 & 7,2 & 4,4 & 9,0 & 7,7
\end{array} \\
& R^{2}=0,894 \quad D W=1,58 \quad S_{e}=1,1 \quad \text { okres } \quad 1967-2006
\end{aligned}
$$

\section{Równanie rozwodów}

$$
\begin{aligned}
& \text { rozw } / \text { lud }=-0,29-0,81\left(X p c_{-4} / X p c_{-6}\right)+0,016\left(G I N I_{-2}+G I N I_{-3}+G I N I_{-4}\right) \\
& 1,6 \quad 4,2 \quad 5,6 \\
& +0,0047 X p c_{-1}+0,78\left(\operatorname{rozw}_{-1} / \operatorname{lud}_{-1}\right)+0,03\left(\mathrm{malz}_{-1} / \mathrm{lud}_{-1}\right)+2,2 u_{-} 67 \_73 \\
& \begin{array}{llll}
4,4 & 8,4 & 2,6 & 4,6
\end{array} \\
& \mathrm{R}^{2}=0,898 \quad \mathrm{~S}_{\mathrm{e}}=0,075 \quad \mathrm{DW}=1,74 \quad \text { okres analizy } 1967-2006
\end{aligned}
$$

\section{Równanie małżeństw}

$$
\begin{aligned}
& \text { malz } / \text { lud }=15,6+2,53\left(X p c_{-3} / X p c_{-8}\right)+0,028 \sum_{i=0}^{2} X p c_{-1}-0,11 \sum_{i=0}^{5} G I N I_{-i} \\
& 5,8 \quad 2,6 \quad 3,2 \quad 4,1 \\
& +1,34 \sum_{i=3}^{5} \operatorname{rozw}_{-i} / \operatorname{lud}_{-i}+1,19 u_{-} d_{-} 88 \\
& 3,7 \quad 4,2 \\
& \mathrm{R}^{2}=0,936 \quad \mathrm{~S}_{\mathrm{e}}=0,41 \quad \mathrm{DW}=0,84 \quad \text { okres analizy 1977-2006 }
\end{aligned}
$$


Stopa bezrobocia: $B B=(1-L / A Z) * 100$

Liczba osób aktywnych zawodowo: $A Z=L+B l i c z$

PKB per capita: $X p c=(X / l u d)$

PKB: $X=(X / L) * L$

gdzie:

$\boldsymbol{A Z}$ - aktywni zawodowo w gospodarce narodowej w tys. osób (wg BAEL);

Blicz - liczba bezrobotnych (wg BAEL) w tys. osób;

$\boldsymbol{B B}$ - stopa bezrobocia w \% ludności aktywnej zawodowo (bezrobotni wg BAEL);

$B B=$ Blicz/AZ

cr - stopa przestępczości, liczba przestępstw (stwierdzonych w zakończonych postępo-

waniach przygotowawczych) na 1000 osób;

GINI - współczynnik zróżnicowania płac (w \%);

inf - wskaźnik cen towarów i usług konsumpcyjnych, wzrost $\mathrm{w} \% \mathrm{w}$ stosunku do roku

poprzedniego;

$\boldsymbol{I} / \boldsymbol{X}$ - stopa inwestycji - nakłady na tworzenie majątku trwałego brutto (w \% PKB);

$\boldsymbol{L}$ - pracujący w gospodarce narodowej przeciętnie w roku według BAEL (w tys. osób);

lud - liczba ludności (w mln osób);

malz - liczba małżeństw (w tys.);

malz/lud - liczba matzeństw na tysiąc mieszkańców

prog - stopień sprywatyzowania w przemyśle (w \%);

rozw - liczba rozwodów (w tys.);

rozw/lud - liczba rozwodów na tysiąc mieszkańców

$S$ - skuteczność egzekwowania kary $\mathrm{S}=\mathrm{Q} / \mathrm{crb}$

$\boldsymbol{Q}$ - wyroki skazujące w sprawach karnych dla dorosłych w sądach I instancji;

$\boldsymbol{c r b}$ - liczba przestępstw stwierdzonych w zakończonych postępowaniach przygotowawczych;

$\boldsymbol{X}-\mathrm{PKB}$, indeks $1990=100$;

$\boldsymbol{X} / \boldsymbol{L}$ - wydajność pracy, PKB na pracującego wg BAEL, indeks $1990=100$;

$\left(\dot{X} / L_{0-7}\right)=\left[(X / L) /(X / L)_{-8}-1\right] / 7$ - średnia stopa wzrostu wydajności pracy w 7 ostatnich latach;

$\boldsymbol{X p c}-$ PKB per capita (osobę, mieszkańca), indeks $1990=100$;

u79_81 u83_87 u90_93 u92_95 u93_03 - zmienne 0-1

Pierwsze dwie cyfry oznaczają pierwszy rok, w którym zmienna przyjmuje wartość 1; ostatnie dwie cyfry oznaczają ostatni rok, w którym zmienna przyjmuje wartość 1 . 


\section{LITERATURA}

Adamski F., 2002, Rodzina. Wymiar społeczno-kulturowy, Wydawnictwo UJ, Kraków.

Bauman Z., 2007, Szanse etyki w zglobalizowanym świecie, Wydawnictwo Znak, Kraków.

Czapiński J., Panek T. (red.), 2009, Diagnoza społeczna 2009, Rada Monitoringu Społecznego, Warszawa.

Divorce and Economic Growth Negatively Correlated, 2008, “The Economist”, 24.07., www.economist.com/world/britain/displaystory.cfm?story_id=11792871.

Fedorczuk M., Kliszko Cz., Męcina J., 2009, Kondycja $i$ warunki dialogu społecznego na poziomie zakładu pracy $w$ opinii jego aktorów [w:] Męcina J. (red.), Dialog społeczny na poziomie zakładu pracy. Między zasadami a realiami, Ministerstwo Pracy i Polityki Społecznej, Warszawa.

Irek W., 2005, Społeczność w świetle rozumu i wiary, Papieski Wydział Teologiczny we Wrocławiu, Wrocław, www.dbc.wroc.pl/Content/2997/Irek2005.pdf.

Jan Paweł II, 1994, List do rodzin (Gratissimam sane), z okazji Roku Rodziny 1994, http://www.npr.prolife.pl/list_do_rodzin_cz1.htm.

Jan Paweł II, 2005, Orędzie na Światowy Dzień Pokoju, http://www.duch.lublin.pl/ teksty/orpokoju05.html, p. 5.

Kocik L., 2006, Rodzina w obliczu wartości i wzorów ponowoczesnego świata, Oficyna Wydawnicza AFM, Kraków.

Kropiwnicki J., 2008, Rodzina i ochrona życia poczętego na sesjach nadzwyczajnych Narodów Zjednoczonych (Kair +5 , Pekin +5 , Istambut +5 ), „Annales. Etyka w życiu gospodarczym", t. 11.2, s. 183-189.

Kumor P., 2009, Współzależność nierówności płac i wzrostu gospodarczego, „Wiadomości Statystyczne", nr 7.

Lachowska B., 2010, Konflikt i facylitacja, jako mechanizmy wzajemnych oddziaływań pracy i rodziny - analiza różnic płciowych [w:] Rostowska T., Peplińska A. (red.), Psychospołeczne aspekty życia rodzinnego, Difin, Warszawa.

Nie ma jak rodzina, 2008, „Komunikat z badań”, nr 40, Centrum Badania Opinii Społecznej, http://www.cbos.pl/SPISKOM.POL/2008/K_040_08.PDF.

Podrez E., 2008, Sokrates a etyka biznesu (rozważania o etycznych źródłach odpowiedzialności), „Annales. Etyka w życiu gospodarczym”, t. 11.1.

Slany K., 2003, Dylematy i kontrowersje wokół matzeństwa i rodziny we wspótczesnym świecie [w:] Balicki J. i in. (red.), Wybrane problemy wspótczesnej demografii, Zakład Demografii UŁ, Łódź.

Stownik języka polskiego PWN, 1999, PWN, Warszawa.

Smith A., 1989, The Theory of Moral Sentiments, MetaLibri, Sao Paulo 2006, www. ibiblio.org/ml/libri/s/SmithA_MoralSentiments_p.pdf, wydanie I, 1759, Teoria uczuć moralnych, PWN, Warszawa.

Sztaudynger J.J., 2009, Rodzinny kapital społeczny a wzrost gospodarczy w Polsce, „Ekonomista”, nr 2.

Sztaudynger J.J., Zatoń W., 2010, Kryzys gospodarczy a kryzys rodziny - analizy symulacyjne, „Prakseologia”, nr 150, s.109-128. 
Śliwerski B., 2011, Wspótczesny spór o istotę i zakres wychowania personalistycznego w Polsce, „Annales. Etyka w życiu gospodarczym”, t. 14.1.

The Economist Intelligence Unit's quality-of-life index, The World in 2005, www.economist.com/media/pdf/QUALITY_OF_LIFE.pdf.

Wallerstein J.S., Blakeslee S., 2006, Druga szansa. Mężczyźni, kobiety i dzieci dziesięć lat po rozwodzie, thum. P. Żak, Wydawnictwo Charaktery, Kielce.

Witkowska J., 2002, Stres $i$ wsparcie $w$ środowisku rodzinnym i zawodowym [w:] Rostowska T., Rostowski J. (red.), Rodzina - rozwój - praca; wybrane zagadnienia, Wyższa Szkoła Informatyki w Łodzi, Łódź.

Zubrzycka E., 1993, Narzeczeństwo, malżeństwo, rodzina, rozwód?, Gdańskie Wydawnictwo Psychologiczne, Gdańsk.

\section{Abstract}

\section{GDP GROWTH, FAMILY AND QUALITY OF LIFE}

In the article we test the hypothesis that the weakening of family ties, as measured by reduction of marriages and a cascade of divorces, caused economic slowdown in Poland. We also suppose (second hypothesis) that the level of economic growth and welfare facilitate life for oneself, make the individuals apart thus limiting the number of marriages and resulting in increasing number of divorces.

We verify these hypotheses by using an econometric model. The model consists of 6 equations and exhibits the feedback between GDP and some variables representing social capital, marriages disintegration especially. The divorce influence on economic growth has parabolic shape - high divorce rates have a negative impact on the economy. High divorce rates have a negative impact on quality of live as well (these are results of research led by the Economist Intelligence Unit).

Prof. zw. dr hab. Jan Jacek Sztaudynger Katedra Ekonometrii Wydział Ekonomiczno-Socjologiczny, Uniwersytet Łódzki 